stmulesen

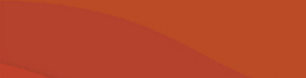

\title{
Co-producing a post-trafficking agenda: collaborating on transforming citizenship in Nepal
}

\author{
Nina Laurie, Diane Richardson, Meena Poudel, Shakti Samuha \& Janet \\ Townsend
}

To cite this article: Nina Laurie, Diane Richardson, Meena Poudel, Shakti Samuha \& Janet Townsend (2015) Co-producing a post-trafficking agenda: collaborating on transforming citizenship in Nepal, Development in Practice, 25:4, 465-477, DOI: 10.1080/09614524.2015.1029436

To link to this article: http://dx.doi.org/10.1080/09614524.2015.1029436

\section{(c) 2015 The Author(s). Published by Taylor \& Francis.}

\section{曲 Published online: 24 Apr 2015.}

Submit your article to this journal $\pi$

Llll Article views: 639

Q View related articles ¿

\section{View Crossmark data}




\title{
Co-producing a post-trafficking agenda: collaborating on transforming citizenship in Nepal
}

\author{
Nina Laurie*, Diane Richardson, Meena Poudel, Shakti Samuha, and Janet Townsend \\ (Received May 30, 2013; accepted May 6, 2014)
}

\begin{abstract}
This article discusses how a new agenda on post-trafficking is gaining momentum through academic and activist anti-trafficking collaborations focused on co-producing knowledge with women who have returned from trafficking situations. Co-production of this nature is important as the issues raised by post-trafficking scenarios are largely ignored in antitrafficking strategies, and the stigmatisation and poverty which women in these circumstances encounter means they rarely have a voice in policy-making. Drawing on research in Nepal, we present four types of co-produced data around transforming citizenship post-trafficking, and reflect on the strategies for generating and using them for advocacy purposes.
\end{abstract}

Cet article traite de la manière dont un nouvel ordre du jour relatif à l'après-traite prend de l'élan grâce à des collaborations anti-traite entre des universitaires et des activistes centrées sur la coproduction de connaissances avec des femmes rescapées de situations de traite. La coproduction de cette sorte est importante car les questions soulevées par les scénarios posttraite sont largement ignorées dans les stratégies de lutte contre la traite, et la stigmatisation et la pauvreté auxquelles se heurtent les femmes dans ces circonstances font qu'elles sont rarement dotées d'une voix lors de la formulation de politiques. En nous inspirant de recherches menées au Népal, nous présentons quatre types de données coproduites sur la transformation de la citoyenneté post-traite, et menons une réflexion sur les stratégies en vue de les générer et de les utiliser à des fins de plaidoyer.

La creciente colaboración entre académicos y activistas ha impulsado la creación de una nueva agenda en torno al tema de las consecuencias sufridas por personas que han sido víctimas del tráfico. El presente artículo analiza la coproducción de conocimientos entre los actores mencionados y mujeres que han sufrido el tráfico, coproducción cuyo valor se hace evidente cuando se constata que las cuestiones surgidas en una situación de postráfico en gran parte son obviadas en el momento en que se elaboran estrategias destinadas a combatir el fenómeno. En este sentido, debido al estigma y la pobreza que deben enfrentar, las mujeres que atraviesan estas circunstancias raras veces pueden expresar su opinión de modo que puedan contribuir a moldear las políticas elaboradas con este fin. Apoyándose en investigaciones realizadas en Nepal, las autoras examinan cuatro ejemplos de información en torno a la transformación de la respuesta ciudadana al tráfico y sus consecuencias posteriores, elaborados en coproducción con las mujeres. Asimismo, analizan la creación de estrategias que podrán ser utilizadas en el trabajo de incidencia.

Keywords: Gender and diversity; Civil society - Partnership; NGOs; Aid - Capacity development; Governance and public policy; Labour and livelihoods - Migration; Rights; South Asia

\footnotetext{
*Corresponding author. Email: Nina.Laurie@ncl.ac.uk
} 


\section{Introduction}

Almost every country in the world is affected by human trafficking. It is a global phenomenon and a priority for many governments. This concern with human trafficking has led to the production of a large body of research over the last two decades, most of which seeks to explain its causes and characteristics, in particular through attempts to quantify which groups of people and how many of them are trafficked, as well as documenting the process and geographical flows of trafficking. Despite this growth in the literature, human trafficking remains a contested concept, with alternative definitions leading to different and, in some cases, divided approaches to antitrafficking analysis and activism (Samarasinghe 2008). Significant work has questioned the "migration"-"trafficking" binary (see, for example, Huijsmans and Baker 2012; O'Connell Davidson 2005). In addition to a lack of conceptual agreement on what trafficking is (and is not), the dominant approach to knowledge production and data collection on trafficking has itself also been criticised (Doezema 2010; Zhang 2009). Regardless of these critiques and nuances, research has often been led by policy frameworks and NGO practices targeting the "rescue" of people, especially women and children, experiencing diverse trafficking situations. In this article we argue that, as a result, little empirical research has addressed post-trafficking. Consequently, scant attention has been given to the development challenges post-trafficking scenarios raise for governments and (I)NGOs. What is also often missing in research that seeks to establish the "facts" about trafficking are the voices, perspectives, and knowledge of those who have themselves been trafficked and who are now attempting to establish new lives post-trafficking. This represents a significant gap in our understanding of trafficking and the success, or not, of anti-trafficking initiatives and interventions.

Extensive debate exists on how marginal voices are included in policy-making following now well-established critiques of participatory development (Cooke and Kothari 2001; Mohan 2004). In this article we examine academic and activist collaboration through knowledge co-production as one aspect of participatory development. Co-production of knowledge is based on bringing different social worlds, in this case practitioners, academic, and community, together for a single goal. Fazey et al. (2012) make a convincing case for seeing knowledge co-production as part of the broader process of knowledge exchange. They place knowledge sharing, generation, co-production, and co-management alongside another group of processes encompassing knowledge transfer, brokerage, storage, exchange, transformation, mobilisation, and translation. In this way they argue for research to address knowledge exchange as "a research topic in its own right" (Fazey et al. 2012, 20). Such reflection on the politics of knowledge co-production is well-established in feminist academic practice, influencing research with diverse women's organisations in the Global South, ${ }^{1}$ as well as with vulnerable mobile groups such as refugees (Houston et al. 2010) and recent immigrants (Mountz et al. 2003). Some of this work examines how knowledge co-production is shaped by collaborative dynamics among academic team members in participatory research settings. Other work focuses on knowledge co-production between academic and activist partners, one of the outcomes of which, as in our case, is academic co-authorship.

In what follows we examine how a new agenda on post-trafficking is gaining momentum through anti-trafficking collaborations based on co-producing knowledge with women who have returned from trafficking situations. As we explain below, this includes with women who now consider themselves leading anti-trafficking advocates working through an increasingly high profile anti-trafficking organisation (Shakti Samuha, Nepal) which they themselves founded in 1996. Following Fazey et al. $(2012,20)$, we approach knowledge exchange on anti-trafficking as a "complex and dynamic process with many interpretations and uncertainties about what makes the process effective and under what circumstances". Our analysis seeks to explore the importance of generating distinct types of co-produced knowledge through different 
spaces and at particular strategic moments. In this way, we reflect on the importance of planned and unplanned opportunities in long-term anti-trafficking advocacy by describing different knowledge-production activities. Our analysis highlights their outcomes and teases out the roles of different actions, and reflective processes, in producing strategic engagements around knowledge exchange with policymakers, academics, and activists, as well as women who have experienced trafficking situations, some of whom identify as anti-trafficking activists. More broadly we aim to highlight how activist-academic forms of co-production on post-trafficking in the context of research in Nepal helps generate new understandings and agendas which, in turn, challenge the ways in which research on trafficking is conducted.

\section{Understanding post-trafficking in Nepal}

Broadly defined, the term post-trafficking describes the processes and practices associated with returning "home" from trafficking situations, for whatever purposes, whether this involves being trafficked internally in one's own country or elsewhere. The research we conducted sought to analyse the post-trafficking experiences of women and because of this the methods used were qualitative. As mentioned above, the research was based on a collaborative partnership with Shakti Samuha, one of the first anti-trafficking organisations in the world to be founded and staffed by women who have experienced trafficking (www.shaktisamuha.org.np). This partnership was important as not only are the issues faced by these women largely ignored, but also the stigmatisation and poverty which they typically encounter means that, even when women gain a voice through processes which transform identities from victims - survivors to activists (as the work of Shakti Samuha indicates), these voices often go unheard in dominant policymaking discourses. Specifically, the research sought to create a space to make the voices of women who have experienced trafficking heard in policy development and implementation, in relation to human rights, through an investigation of how post-trafficking issues intersect with access to citizenship. Another partnership was also established with the International Organization for Migration (IOM) in Nepal once the funding had been awarded and provided further opportunities to influence the process by which knowledge could be co-produced, as explained in more detail later. ${ }^{2}$

Nepal was chosen because it is one of the source countries for trafficked women in South Asia. Women are trafficked to India through the open border and also on to other countries, including those in Southeast Asia and the Middle East (Poudel, 2011). Although estimates are difficult to interpret, the US State Department TIP Report estimates that between 10,000 and 15,000 women and children are trafficked from Nepal to India and Gulf countries annually (US TIP 2012). Another reason for choosing Nepal is that women returning from trafficking situations, while representing one of the most stigmatised, vulnerable groups, are also beginning to organise around rights to livelihoods. This is a key aspect of the anti-trafficking work undertaken by Shakti Samuha. A further reason for the choice of Nepal is that it is undergoing democratic reform through a constitutional process following a decade of civil war. Our project explored the intersections of sexuality, gender, and citizenship in women's livelihood strategies as these new democratic processes, supported by national and transnational communities, unfolded. The first multi-party democratic constitution in Nepal was ratified in 1990. The civil war lasted from February 1996 until November 2006. In April 2006 an Interim Assembly was enforced following the People's Movement II, the revival of the dissolved parliament, and the brokering of peace talks through a Comprehensive Peace Accord (CPA) with the Maoist rebels (GoN 2007). Two years later an elected Constituent Assembly (CA) was convened in April 2008 which declared the country to be a Federal Democratic Republic after ending the Constitutional Monarchical system introduced in 1990 through the People's Movement I. The original mandate 
to draft the new constitution by May 2010 was extended several times until, in May 2012, the Supreme Court rejected any further extensions to the Constituent Assembly as a move towards the setting up of elections to form a new democratically elected government. Elections took place on 19 November 2013, the new coalition was sworn in on 25 February 2014, and public feedback on the constitutional drafting process was due to be completed by January 2015 . Following this, the CA will undertake a detailed discussion of each article before the Constitution is certified by the Chair of the Constitution Drafting Committee and subsequently signed off by the President.

The research findings (see Laurie et al. forthcoming; Townsend et al. 2015) established that the difficulties many women face on leaving trafficking situations present severe challenges to them in making new lives and forging sustainable livelihoods. Shakti Samuha and other anti-trafficking organisations have actively lobbied for rights to livelihoods and changes in citizenship rules which discriminate against women, who historically have needed a male relative to endorse their application for citizenship on reaching 16 years of age (Pant and Standing 2011; Richardson, Poudel, and Laurie 2009). For many women returning from trafficking situations the stigma and family rejection they encounter makes this process formidable, often effectively making them stateless in their home country upon return. ${ }^{3}$ This includes being unable to confer citizenship on their children, either because they lack citizenship themselves or because their children were born in trafficking situations (lacking a known father) (Townsend et al. 2015). These issues have fundamentally shaped the focus of our research, framing how, where, and why co-production occurred.

Although our findings highlight an extreme case of discrimination, and draw on experiences taking place in a particular political context, our emphasis on co-production has implications for the approach to research on post-trafficking more generally. This includes in contexts where the discrimination may not be so obvious or where citizenship may be less central.

\section{Methods and approach}

Our study ran from November 2009 to April 2012. ${ }^{4}$ In this article we draw and reflect on four sources of qualitative data which represent different levels and forms of collaboration and co-production. First, the overall framing of the discussion has been informed by the core data collection for the wider project which involved 37 interviews conducted with Nepalese women who have returned from diverse trafficking situations. Although we have not quoted directly from these data here, our interview analysis highlighted that professionalisation was an increasingly important issue for anti-trafficking groups in Nepal. It was therefore decided that a further subset of nine interviews would be conducted with women who had left trafficking situations and who identify as activists, in order to explore these issues in more depth. These interviews, which we draw on directly in this article, were carried out between October and November 2011 with members of the Executive Committee of Shakti Samuha. They took place midway between the study's two large co-hosted workshop activities (see below) and, in the case of senior long-serving Executive Committee members, sometimes became part of reflective learning processes in the ongoing dialogue among the research activist-academic partners. As a result, the new research theme and data source represented a more overt co-productive engagement with Shakti Samuha as research collaborator-participants, as do the third and fourth data sources. ${ }^{5}$

The third source of data come from the two large co-hosted workshops: an activist workshop to debate emerging findings (February 2010) and a policy workshop "Making Livelihoods Post Trafficking: Sexuality, Citizenship and Stigma" (November 2011), both of which took place in Kathmandu. The fourth set of data emerges from information collected by Shakti Samuha as a feature of the way they work with women who seek to become members of their organisation. 
Specifically, this data collection relates to their understanding of trafficked identities not only as part of membership formation, but also in terms of raising public awareness about what a trafficked identity means and what being a trafficked activist involves. It is not the focus of this paper to explore these issues and processes; rather here we explore what co-production means in practice through a reflective analysis of how a sample of this data was selected, with input from the research project team, for use in advocacy focused on the Constituent Assembly (CA). The opportunity for this advocacy moment arose directly from the co-hosted/co-produced activist workshop above (part of the third data source).

We draw on extensive participant observation in the co-hosted events and follow-up advocacy activities, as well as linguistic data from interviews with the Shakti Executive Committee (the second data source) which included reflections upon these actions. The presentation of these four types of data is therefore purposeful. The aim is to show the diverse ways in which collaboration and co-production were woven through the project at different levels, in order to ensure trafficked women's perspectives are made visible, and foregrounded in data production, analysis, and dissemination.

\section{Collaboration, co-production, and a shared agenda}

The collaborative partnership with Shakti Samuha shaped the research's focus on citizenship and livelihoods from the outset, prioritising in particular the situation of women returning from trafficking situations. Although founded in 1996, Shakti Samuha initially struggled to gain legal registration as an NGO because the founding members did not at that time hold citizenship cards. This lived reality sparked a longstanding interest in improving trafficked women's citizenship rights, which became a core focus of the research.

Growing from a small base, Shakti Samuha now provides solidarity in a number of ways for women who have left trafficking situations, through hostels, including a working women's hostel, outreach programmes, and livelihoods training, including in non-traditional skills. Its work was recognised in 2013 by the Ramon Magsaysay Award, which celebrates courage in serving others and is widely understood to be Asia's Nobel Prize. While Shakti Samuha has grown significantly as an organisation in recent years, managing a number of projects funded by a range of international donors including Save the Children, Free the Slaves (Shakti Samuha 2008), and more recently IOM Nepal's economic empowerment programme for returnees, to this day only women who have experienced trafficking can become members and serve on the Executive Committee.

As part of its increasingly diverse portfolio of advocacy activities the research project was Shakti Samuha's first move into academic research. At Shakti Samuha's request, research training became a central element of the research project's design; delivered through a two-year modularised programme for Executive Committee members. In this way, capacity building for knowledge co-production was emphasised from the outset. The training was conceptual and also involved practical skills.

"The research training taught me the way to deal with any individual. I also learnt the way to think about any incident, in theory ... I also learnt the skill to start any conversations while doing research." (Interview, Executive Committee Member, Bal Kumari, 2011)

Overall the training programme reflected a strong sense of the need for trafficked women to be authors of their own stories.

\footnotetext{
"Shakti has been doing research funded by other donors and recruiting researchers for us. But this is us doing research for ourselves and it is very important to analyse our social world from our perspective." (Interview, Executive Committee Member, Charimaya Tamang, 2011)
} 
In the feedback session after completing the first training module, the same Executive Committee member stated that the training would enable them to make informed decisions when dealing with the media and other researchers: "Now we know what to ask researchers/media interviewers and foreign researchers coming and taping our stories." This reflection indicates that engagement in knowledge exchange not only involved co-production but also knowledge sharing as part of "grassroots attempts to operationalise empowerment" (Kabeer 2004, 224).

Shakti Samuha argue that capacity building through research training for women who have experienced trafficking themselves is more likely to ensure that policy development is based on real not assumed needs. They highlighted this point with their presentation on the importance of research training ("A Reflection on the Journey from Trafficking Survivor to Social Researcher") at the policy workshop. In this presentation Executive Committee Member Laxmi Puri argued that: "Research conducted by survivors themselves would be more effective and help to identify the real status of trafficking survivors, identify their needs and make recommendations to stakeholders in order to fulfil their actual needs." This was a significant forum in which to make such a point, as this policy workshop (co-hosted by Shakti Samuha, the research team, and the IOM) attracted more than 100 participants, including senior policymakers, members of the Parliament Women's Caucus, and several CA members including members of the Fundamental Rights Committee. It was opened by the Minister for Women, Children and Social Welfare and chaired by the President of Shakti Samuha. The event served to highlight how policy development could be made more responsive to women's needs if building their research capacity is prioritised. Towards the end of their presentation Shakti Samuha outlined an agenda for future research and have since developed their own research proposal ("Access to Justice? Social impacts on women after filing legal cases against traffickers in post-trafficking situations"). While sharing knowledge in this way indicates the complex and sometimes drawn out stages involved in making knowledge co-production part of successful advocacy, this is by no means a straightforward process. In this instance, while government ministers, NGO directors, and CA members listened attentively to Shakti Samuha's presentation, the local media turned their camera off when Laxmi Puri took the platform. When challenged about why the cameras stayed on for donors and ministers but not for Shakti Samuha as co-hosts of the event, the response was merely a shrug. Co-producing new knowledge about anti-trafficking with women who had experienced trafficking, even those leading recognised NGOs, was clearly not seen as newsworthy.

\section{Scaling up knowledge transfer and co-production}

The research project's focus on the need to build capacity that enables trafficked women to become co-producers of knowledge on anti-trafficking was also scaled up through two additional training programmes taking advantage of moments when Shakti Samuha was playing a leadership role in national and international level anti-trafficking networks due to its growing profile. The first was during Shakti Samuha's period as chair of the Alliance Against Trafficking in Women and Children in Nepal, AATWIN (the national umbrella organisation for Nepal's anti-trafficking organisations). A two-day workshop (in November 2010) for AATWIN's 35 membership organisations promoted understanding of anti-trafficking's relationship with human rights. The second was a three-month research training programme (July-September 2012) jointly for AATWIN and the Global Alliance Against the Trafficking of Women (GAATW). ${ }^{6}$ Shakti Samuha was also a member of GAATW's board at the time. The training aimed to build capacity in generating baseline data on livelihood needs for future international lobbying around the UN optional protocol on trafficking, which the UN signed in 2000. This protocol (the Palermo protocol) aims to "Prevent, Suppress and Punish Trafficking in 
Persons, Especially Women and Children". An aspect of the Convention against Transnational Organised Crime, it came into force internationally in 2003 and has since been ratified by more than 117 countries. Nepal has not yet signed.

Another important feature of the emphasis on the co-production of knowledge with women who have returned from trafficking situations (including women activists such as the Shakti Samuha leadership, as well as ordinary members) was the joint hosting of the activist workshop, in Kathmandu in February 2011. By reviewing NGO programmes' strategic development in the light of five core themes derived from research findings, ${ }^{7}$ the aim of the workshop was to generate co-produced advocacy-focused data with a wide group of anti-trafficking activists. This workshop was purposefully scheduled to coincide with the last stages of submission of the first drafts of various thematic committees to the CA writing the new constitution. This example highlights the importance of not only generating knowledge exchange opportunities which aim to co-produce new knowledge on anti-trafficking interventions, but also points to the way in which well-timed opportunities are able to take advantage of crossover interests around a specific issue such as citizenship. While women leaving trafficking situations experience citizenship in particular ways, some of the exclusions they face are also applicable to women in general. This is reflected in the alliances made through both the activist workshop and follow-up lobbying of the CA, as we elaborate below.

\section{Activist workshop}

Over 80 participants attended the activist workshop, including anti-trafficking NGOs, donors, 37 women who had experienced trafficking (some, but not all of whom, were members of Shakti Samuha), and high-level government representatives including members of the CA. The workshop acted as a catalyst in stimulating a chain of events that led to policy debate and political lobbying and, subsequently, to a number of recommendations on rights of citizenship being included in the draft Constitution and the National Plan of Action on Trafficking (MWCSW 2012). The national action plan is currently being implemented and the draft constitution is currently in the hands of the new CA (see below).

The research methodology sought to bring trafficked women's perspectives into policy debates and responses. This had a direct effect on how some workshop participants started to envisage how democratic mechanisms could be used to support women in post-trafficking situations in specific local settings. For example, expressing a clear appreciation of what notions of active citizenship mean in practice, one participant from a grassroots NGO suggested that: "We should make each district and Village Development Committee [VDC - local government office] allocate a budget for women affected from trafficking and ask for their commitments on raising awareness on citizenship and livelihoods and establish rehabilitation centre" (Workshop evaluation feedback, February 2011). Another spoke about the need to follow up the workshop with strategic lobbying of the national Constituent Assembly process: "The issues raised should be collated and submitted to the Chairperson of the Constitutional Committee, for Shakti Samuha to take an initiation and a follow up, this will make change" (Workshop evaluation feedback, February 2011).

As a result, a number of demands concerning citizenship rights for trafficked women and their children came out of the workshop, which Shakti Samuha submitted to various bodies of the Constituent Assembly (CA) or constitution drafting committees (see Table 1). ${ }^{8}$ These fed directly into debates on citizenship in the Constitution writing process through ongoing dialogue with relevant subject committees of the CA and the Women's Caucus of the legislative parliament. ${ }^{9}$ 
Table 1. Shakti Samuha's proposal to change current citizenship provision in new constitution.

\section{March 2011, Kathmandu}

These points were raised in February activists' workshop, promoted through the media campaign, shared with anti-trafficking feminists, human rights activists and wider NGO communities and handed in to CA members/Fundamental Rights Committee Chair.

1. Citizenship to women and men should be granted based on birth, no parents' endorsement required.

2. Citizenship for children born abroad to the mothers who were sexually exploited abroad and now living in Nepal with their mothers should be granted based on state endorsement.

3. Considering the geopolitical location of Nepal and sensitivity attached to citizenship, our demand is to have a special provision. In regard to trafficked women, it should be the state formulating special provisions to grant citizenship to trafficked women and their children and it should be stated in the upcoming constitution.

4. Until radical changes are made, current provision must be amended in line of a provision to provide descent citizenship through mother as well.

5. The gender-based discrimination should be ended: marrying a foreigner, employment, giving citizenship rights to offspring, acquiring Naturalised citizenship should be based on Nepal's agreement with CEDAW ${ }^{\mathrm{a}}$ and other human rights commitments the country has signed/ratified.

6. Children special: The state should be responsible for providing citizenship to those whose parental detail or descent is unknown.

Note: ${ }^{a}$ Convention on the Elimination of All Forms of Discrimination Against Women.

\section{Lobbying the government and Constituent Assembly on anti-trafficking and citizenship}

The process through which lobbying occurs illustrates how the co-production of knowledge for advocacy purposes operates on the ground, often through networks of trust and overlapping spaces of influence and jurisdiction. Such networks and opportunities can be the result of unanticipated alliances and opportunities, as well as more long-term strategic network building. Two examples illustrate these different contexts through which the co-production of knowledge generated by the research influenced attention to post-trafficking livelihoods and citizenship issues in policy-making in Nepal. The first example relates to the drafting process for the National Plan of Action on Trafficking. In her role as the IOM Nepal National Programme Advisor, team member Dr Poudel was invited to be a technical expert to the National Committee Controlling Human Trafficking (NCCHT) mandated to formulate, revise, and implement the National Plan of Action on Trafficking. Shakti Samuha also served on this committee as a member representing women who had themselves experienced trafficking. While Dr Poudel's long-term relationship with Shakti Samuha pre-dated the research project, the partnership with the IOM did not. Rather this was established after the award of the research funding, as by this time she was employed by the IOM. Subsequently a partnership was formed and a sub-contractual arrangement negotiated between Newcastle University and the IOM in Nepal. This funder agreed because such an arrangement had the potential to influence policy-making at a high level.

The new partnership brought to the fore the need to think and work through postionality issues relating to insider/outsider status and more explicitly the knowledge of research teams members. (As part of this process these issues became a permanent item on research group meeting agendas and have influenced the arguments in this article.) The combination of Shakti Samuha's growing presence on the anti-trafficking scene in Nepal, combined with the wide reach and profile of IOM's UN networks, helped ensure broad-ranging engagement with the project's dissemination activities and facilitated knowledge co-production with wider groups in the activist and policy workshops. The end result of the three-way collaboration influenced policy because in March 2012 the Cabinet endorsed the recommendations, informed by the research findings, for the provision of support for women post-trafficking through access to social rights of citizenship (e.g. housing, medical treatment, victim support fund, education, livelihoods) (National Human Rights Commission 2012). 
The second example relates to lobbying the CA on citizenship following the activist workshop in February 2011. Immediately after attending the workshop, the Chair of the CA Fundamental Rights Committee, Ms Binda Pandey, who had been an active and supportive participant in the research project, contacted Dr Poudel to solicit from Shakti Samuha case study examples of returnee trafficked women's exclusion from forms of citizenship, with a view to presenting them to the CA. They both went to the Shakti Samuha office the next day and whilst sitting in a room together with the founding members, including the current president, they leafed through compilations of case histories which are part of the Shakti Samuha membership process.

The case study interviews create a fabric of common and diverse threads. Violence was explicit in the lives of many of the women in our research and this is reflected in the fact that violence against women featured explicitly in seven of the 13 case studies presented to the CA. In some it was the reason for failure to secure citizenship and be able to register a birth, as the following testimonial from one cases indicate.

"I fell in love with a boy when I was 21 and married him. I gave birth to a boy after one year. I started facing physical and psychological violence immediately after I became pregnant and later he left me ... I started asking my husband to support in making my citizenship certificate and help in registering the baby's birth but he denied. I tried to make this from my maternal home but VDC secretary there also refused to do so. We both are in a big trouble because we don't have this essential document and we don't have our future." (Case history 1)

In a number of other cases women also approached their VDC to process their citizenship applications without success.

While our research reveals how officials are often unsympathetic to women without citizenship, because they have been trafficked, the cases presented to the CA also suggests that this is a more generic problem for women who do not have the support of a husband or father, for whatever reason.

"At the age of 19 , one of my friends showed me a man and requested and forced me to marry with
him ... later on I came to find that he already had two wives along with children. After a year, I also
gave birth to a boy but I didn't get any kind of care and support from my husband. He started to abuse
me verbally, emotionally and physically by beating and saying bad words to me ... I couldn't stay with
him ... My father didn't agree to give endorsement for my citizenship ... and my husband also denied
of giving me citizenship in his name. My son also doesn't have birth certificate." (Case history 2)

A further and separate thread of deprivation of citizenship is woven for many women through inter-caste marriages. One woman in the case histories submitted to the CA was not accepted by her husband's family and in another case a woman's marriage was not accepted by her own parents. Our research indicates how bias against women in the processes of accessing citizenship is also compounded by the mutually re-enforcing links between poverty and trafficking (Laurie et al. 2010.) Testimonial evidence in another case history submitted to the CA also makes this link very clear.

\footnotetext{
"Because I am from a very poor family and I am illiterate, I was lured to a fake marriage and trafficked to Kuwait as a domestic worker ... I started to face a lot of domestic and sexual violence from my landlord. After my landlord found I was pregnant with his child, he snatched away all the documents and complained to the police that I was an illegal immigrant. At the custody I met Nepali woman who later helped me and my child to be rescued from there. We came to Nepal and started living with this woman ... Later I met a social mobiliser who told me that this woman whom I was living with was also a broker and will potentially traffick me again." (Case history 3 )
} 
The woman who shared this testimonial is from an ethnic group (Tamang) often stigmatised for assumed high levels of trafficking within their communities, indicating how the link between poverty and trafficking is also often racialised for some groups (see also Laurie et al. 2011).

A major preoccupation in the majority of the cases presented to the CA (10 out of 13) was the future of children. This is explained by the fact that if a husband or male relative will not support the mother's application for citizenship, a birth cannot be registered, unless the husband/male relative does it himself. This rarely happens and in this situation, the women said, the child cannot go to school, get a job, or get citizenship when they reach 16 years old. In three of the cases the fathers of the trafficked women refused to endorse their citizenship claim. In five other cases, a father's support was not possible because he had died. For some of these women, as well as others, husbands would not endorse them either; this included two cases where the women were divorced.

In sum it seems likely from our analysis of the 13 cases documented by Shakti Samuha and selected by the Chair of the Fundamental Right's Committee to present to the CA, that in 11 cases simply having been trafficked and family reactions to this precluded women from citizenship. Each of the 13 cases represents a very real demand for the right to citizenship. In knowledge exchange terms these cases were translated and mobilised for advocacy through Shakti Samuha's membership archives providing mechanisms for knowledge storage, and the process of co-selecting cases serving as a form of knowledge brokerage.

\section{Conclusion}

Through Shakti Samuha's advocacy, trafficked women without citizenship are lobbying for new policies from a new Constituent Assembly in Nepal that will grant them citizenship in their own right. To this end, the research interviews, the activist workshop, letters to the different CA committees, and the 13 cases presented by the Chair of the Fundamental Rights Committee have been highly successful lobbying tools. The workshop in particular received extensive media coverage, including interviews on Nepali TV and radio stations, and print articles in the Nepali press. It also prompted follow-on events targeting the CA process organised by various NGOs, human rights groups, and media houses. In each of these events knowledge about trafficking continued to be coproduced through engagement between women who have experienced trafficking and identify to different degrees as anti-trafficking activists and leaders, and state and other civil society actors. Through these processes new understandings of anti-trafficking have been generated, setting a new agenda and parameters for the debate, as well as challenging the ways in which research on trafficking is traditionally conducted.

Engaging in research to help bring about change is never a straightforward, unilinear process. Nor is it easy to capture in a snapshot. Sometimes unexpected collaborations come about through changed circumstances, as we have tried to illustrate with the presentation and discussion of the four different kinds of co-produced data in this article. We have also suggested that for such circumstances to turn into opportunities, overlapping spaces of influence and jurisdiction need to be aligned through networks of trust built up over long periods of time. This, we would argue, is at the heart of a politically engaged understanding of collaboration which aims to raise the profile and listen to the voices of excluded and marginalised actors.

Despite the dissolution of the CA in 2012, debates on citizenship among anti-trafficking, women's rights, and political sectors continued and some closure was achieved following the lobbying on citizenship exclusion post-trafficking. The CA elections in November 2013 created more space to follow through on these initiatives as the political parties agreed to own the progress made by the previous CA. As a result, the mechanisms for taking proposals forward are now in place following the inclusion of a recommendation in the draft Constitution that "children without having a 
father's known identity" should be granted rights of citizenship. This was approved in March 2012 before the CA was dissolved (Fundamental Rights Committee Submission to the CA 2012, 5) and the draft was saved in the CA secretariat, which has now been reopened. This, we would argue, is a step along the path to transforming citizenship in Nepal.

\section{Acknowledgements}

We would like express our thanks to all the returnee trafficked women who shared their stories with us. We are grateful for the input of wider stakeholders fighting for inclusive forms of citizenship and better understandings of trafficking in Nepal, especially the Chair of the Fundamental Rights Committee (Ms Bindu Pandey) and the Special Rapporteur on the Nepal TIP report (Ms Padma Mathema). We are indebted to members of our Advisory Panel (Cindy Berman, Maggie O'Neill, Katherine Rankin, and Farida Akhter) for their support throughout the project, especially on methodological issues.

\section{Disclosure statement}

No potential conflict of interest was reported by the author(s).

\section{Notes on contributors}

Nina Laurie is a Professor in the School of Geography, Politics, and Sociology, Newcastle University, UK. Her research explores how social and advocacy movements generate and mobilise around diverse identity issues. Her publications include Working the Spaces of Neoliberalism (2006) and Indigenous Development (2009).

Diane Richardson is a Professor in the School of Geography, Politics, and Sociology, Newcastle University, UK. She researches gender, sexuality, and minorities' rights of citizenship. Her publications include Rethinking Sexuality (2000), Contesting Recognition (2011), Sexuality, Equality and Diversity (2012), and Introducing Gender and Women's Studies (2015).

Meena Poudel works on development and socially and politically marginalised groups in Asia. She has extensive experience on anti-trafficking and is the author of Dealing with Hidden Issues: Social Rejection Experienced by Trafficked Women in Nepal (2009).

Shakti Samuha is the first organisation in Nepal to be established and run by survivors. Founded in 1996, it focuses on organising and empowering returning trafficking survivors by providing shelter, legal aid, vocational training, and counselling.

Janet Townsend is a Visiting Fellow in the School of Geography, Politics, and Sociology, Newcastle University, UK. She works with poor women in low income countries on poverty and self-empowerment. Her publications include Women and Power (1999), Knowledge, Power and Development Agendas (2002), and NGOs and the State in the 21st Century (2006).

\section{Notes}

1. Illustrative examples include Peake and Trotz's (1999) collaboration with "Red Thread" in Guyana (www.facebook.com/RedThreadWomenGuyana/info) and the work of the Sangtin Writers with Richa Nagar (2006) focusing on feminist thought and activism in India.

2. Both partnerships were initially made possible by the long-term engagement of one of the team members. Dr Poudel had a longstanding relationship with Shakti Samuha, including in her role in Oxfam (Programme manager 1996-99, and as Oxfam country director for Nepal for 2000-05), prior to coming to Newcastle University to do a $\mathrm{PhD}$ on anti-trafficking. After that, as this project took time to secure funding, Dr Poudel took up a position with the International Organization for Migration (IOM) Mission in Kathmandu, in the meantime. Once the project was funded, a partnership was established with the IOM mission in Nepal to facilitate Dr Poudel's continued participation in the research.

3. Historically the right to citizenship was passed through the paternal line and linked to particular forms of kinship via the endorsement of a male relative, typically a woman's father or, through marriage, via her husband. This was distinct from the state conferring citizenship. 
4. This article is based on findings from the Post Trafficking Livelihoods in Nepal: Women, Sexuality and Citizenship project. This work was supported by The Economic and Social Research Council (ESRC) [Res-062-23-1490].

5. A further 15 stakeholder interviews with activists, key personnel in NGOs, and government were conducted. The study also analysed discourses and emerging policies on trafficking and citizenship in Nepal, and tracked the evolution of debates in the Constituent Assembly, convened in 2008 to draft a new constitution.

6. See Conference Report: Accessed 29 April 2014.

7. A leading global anti-trafficking network based in Bangkok. Accessed 29 April 2014, http://www. gaatw.org/. It recently launched its own international academic and policy journal, Anti-trafficking Review, http://www.antitraffickingreview.org/.

8. (a) Committee reviewing current citizenship provision; (b) inputs to National Plan of Action to Combat Trafficking (NPA); (c) reviewing NGO sponsored rehabilitation schemes; (d) examining mainstream approaches to post-trafficking livelihoods; and (e) challenges to the social reintegration of the women.

9. The Chair of the Women's Caucus, the Fundamental Rights Committee, the Chair of the Constituent Assembly, and Thematic Committee as well as different political parties.

\section{References}

Cooke, B., and U. Kothari, Eds. 2001. Participation: the New Tyranny? London, Zed Books.

Doezema, J. 2010. Sex Slaves and Discourse Masters: The Construction of Trafficking. London: Zed Books.

Fazey, I., A. C. Evely, M. S. Reed, L. C. Stringer, J. Kruijsen, P. C. L. White, A. Newsham, L. Jin, et al. 2012. "Knowledge Exchange: A Review and Research Agenda for Environmental Management." Environmental Conservation 40: 19-36.

Fundamental Rights Committee. 2012. Fundamental Rights Committee Submission to the Constituent Assembly of Nepal 2012. Kathmandu: Fundamental Rights Committee.

Government of Nepal GoN. 2007. The Interim Constitution of Nepal 2007. Kathmandu: Government of Nepal. Accessed April 25, 2013. www.worldstatesmen.org/Nepal_Interim_Constitution2007.pdf

Houston, S., J. D. McLean, J. Hyndman, and A. Jamal. 2010. "Still Methodologically Becoming: Collaboration, Feminist Politics and 'Team Ismaili'." Gender, Place and Culture 17 (1): 61-79.

Huijsmans, R., and S. Baker. 2012. “Child Trafficking: 'Worst Form' of Child Labour, or Worst Approach to Young Migrants?" Development and Change 43 (4): 919-946.

Kabeer, N. 2004. Reversed Realities. Gender Hierarchies in Development Thought. London: Verso.

Laurie, N., D. Richardson, M. Poudel, and J. G. Townsend. Forthcoming. "Post-Trafficking Bordering Practice: Marking and Stretching Borders." Political Geography.

Laurie, N., M. Poudel, D. Richardson, and J.G. Townsend. 2010. "Sexual Trafficking, Poverty, Marginalization and Citizenship in Nepal." ESRC (Project Res-062-23-1490) WORKING PAPER. Accessed March 19 $9^{\text {th }}$ 2013. http://www.posttraffickingnepal.co.uk/cgi-bin/download.cgi

Laurie, N., M. Poudel, D. Richardson, and J.G. Townsend. 2011. "Crossing Back Over the Open Border: Geographies of Post Trafficking Citizenship in Nepal". (ESRC Project Res-062-23-1490) WORKING PAPER. Accessed March $19^{\text {th }}$ 2013. http://www.posttraffickingnepal.co.uk/cgi-bin/download.cgi

Ministry of Women, Children and Social Welfare (MWCSW). 2012. "National Plan of Action Against Trafficking in Children and Women for Sexual and Labour Exploitation." Kathmandu: Government of Nepal.

Mohan, G. 2004. Beyond Participation Strategies for Deeper Empowerment. London: Mendely.

Mountz, A., I. Miyares, R. Wright, and A. Bailey. 2003. "Methodologically Becoming: Power, Knowledge and Team Research." Gender, Place and Culture 10 (1): 29-46.

National Human Rights Commission. 2012. Trafficking in Person Especially on Women and Children in Nepal. National Report 2011. Lalitpur: Office of the Special Rapporteur on Trafficking in Women and Children.

O'Connell Davidson, J. 2005. Children in the Global Sex Trade. Cambridge: Polity Press.

Pant, B., and K. Standing. 2011. "Citizenship Rights and Women's Roles in Development in Post-Conflict Nepal." Gender and Development 19 (3): 409-421.

Peake, P., and A. Trotz. 1999. Gender, Ethnicity and Place: Women and Identities in Guyana. London: Routledge.

Poudel, M. 2011. Dealing with Hidden Issues: Social Rejection Experienced by Trafficked Women in Nepal. Saarbrucken: Lambert Academic Publishing. 
Richardson, D., M. Poudel, and N. Laurie. 2009. "Sexual Trafficking in Nepal: Constructing Citizenship and Livelihoods." Gender, Place and Culture 16 (3): 257-278.

Samarasinghe, V. 2008. Female Sex Trafficking in Asia. The Resilience of Patriarchy in a Changing World. London: Routledge.

Samuha, Shakti. "2008 Annual Report." Kathmandu: Shakti Samuha.

Townsend, J. G., N. Laurie, M. Poudel, and D. Richardson. 2015. "Gender, Trafficking and Citizenship in Nepal.” In A. Coles, L. Gray, and J. Momsem (eds) Handbook of Gender and Development. London: Routledge.

United States Department of State. 2012. "Trafficking in Persons Report (TIP) (annual)." Accessed April 25, 2013. http://www.state.gov/j/tip/rls/tiprpt/2012/

Writers, Sangtin, and Richa Nagar. 2006. Playing with Fire: Feminist Thought and Activism Through Seven Lives in India. Minneapolis: University of Minnesota Press.

Zhang, S. X. 2009. "Beyond the 'Natasha' Story - A Review and Critique of Current Research on Sex Trafficking." Global Crime 10 (3): 178-195. 